\title{
SOME REPRODUCTIVE PERFORMANCE OF MALE LAMBS AND FEEDING VALUES OF RATIONS AS AFFECTED BY SUPPLEMENTATION OF DIFFERENT SELENIUM SOURCES
}

\author{
G. A. Abd El-Hafez ${ }^{1}$, G. M. A. Solouma ${ }^{2}$, A. Y. Kassab ${ }^{3}$ and A. S. Ali ${ }^{2}$ \\ ${ }^{1}$ Department of Animal Production, Faculty of Agriculture, Assiut University. Egypt \\ ${ }^{2}$ Department of Animal Production, Faculty of Agriculture, Sohag University, Egypt \\ ${ }^{3}$ Department of Animal Production, Faculty of Agriculture, New Valley Branch, Assiut University, \\ Egypt
}

(Received 3/2/2016, accepted 22/3/2016)

\section{SUMMARY}

$\mathrm{T}$

he aim of this study was to evaluate some reproductive performance of male lambs, digestibility coefficients and feeding values of rations as affected by supplementation of different selenium (Se) sources. Twenty-four healthy Sohagi male lambs (7-8 month old and $24.47 \pm 0.15 \mathrm{~kg}$ body weight) were randomly assigned into four dietary treatment groups ( 6 animals each).The experiment was extended for 25-weeks after two weeks as adaptation period. Basal diet was formulated to meet the nutritional requirements according to the NRC (1985) except Se. Lambs in the first group were fed a basal diet as a control (T0) without supplement whereas lambs in groups T1, T2, and T3 were fed the basal diet supplemented with $0.1 \mathrm{mg} / \mathrm{kg}$ DM sodium selenite, vitamin E and selenium and selenized yeast (Se-yeast T3) , respectively. Three rams from each group (average body weight $44.21 \pm 4.90 \mathrm{~kg}$ ) of feeding trial were placed in metabolic cages for perform four digestibility coefficients trials to evaluate the digestibility and feeding values of the experimental rations. Five-day preliminary period was followed by a collection period of ten days with quantitative collection the feces. Blood samples from three animals in each group were collected before offering feed and water throughout the experimental period at $0,1,2,3,4$ and 5 months of the experimental period . Results showed that ration supplemented with selenized yeast (T3) had a higher DM, OM, CP, EE and NFE digestibility coefficients than the other three treatments and the differences mostly were significant in most nutrients between T3 and each of T1 and control (T0) group. Generally, digestibility coefficients of DM were $66.66 \%, 68.94 \%, 70.31 \%$, and $71.98 \%$ for control (T0), T1, T2 and T3, respectively. Also the values of TDN and DCP were behaved similar trend among dietary treatments as well as the digestion coefficients of all nutrients. The present results illustrated that testes weight recorded higher values in T3, T2, T1 compared to control group (T0), but the differences among treatments were not significant. In addition, the concentrations of selenium in testes were significantly $(\mathrm{P}<0.01)$ higher in $\mathrm{T} 3$, followed by $\mathrm{T} 2$ and $\mathrm{T} 1$, while the lowest value was recorded in the control group (T0), with significant difference between each other. Also, results illustrated that values of testes circumference, testes volume and testosterone concentration at the beginning of experiment showed no significant differences among treatments, while at 1, 2, 3, 4 and 5 months of experimental period T3 group recorded higher $(\mathrm{p}<0.01)$ or values of three mentioned testes parameters compared with T2, T1 and control (T0) treatments. Generally, $\mathrm{T} 3$ and $\mathrm{T} 2$ recorded higher and significantly values in comparison with $\mathrm{T} 1$ and control group (T0). Also, data showed that both diameter of testes and plasma testosterone concentration increased with advancing of age. In addition, values of plasma thyroid hormones concentrations recorded significantly $(\mathrm{p}<0.01)$ higher values as a results of supplementation of different sources of selenium compared to control group. Moreover, concentration of both hormones in T3 selenized yeast (Se-yeast) and T2 (vitamin E and selenium) showed significantly $(\mathrm{p}<0.01)$ higher activity of both thyroid hormones in comparison with $\mathrm{T} 1$ (sodium selenite) and control (T0) groups. Also, both hormones concentrations increased with advancing age. It can be concluded that supplementation of selenium in the ration of sheep especially in the form of selenized yeast (Se-yeast) led to an improvement in nutritive value of rations and reproductive performance through the favorable effects on weight, testes diameters and testosterone concentration as well as the thyroid hormones concentrations in blood of male lambs.

Keywords: Selenium sources, digestibility reproductive performance, growing lambs 


\section{INTRODUCTION}

Animals that mainly consume home produced roughage and easily can suffer from Se deficiency if they are not supplemented in an appropriate way. Se deficiency induces oxidative stress and reduced fertility, which was associated with higher level lipids peroxidation. Sanchez-Gutierrez et al., (2008) reported that Se deficiency reduced the number and differentiation of germ cell. In addition, MarinGuzmanet al., (2000) reported that Se is important during testicular development. The improvement in reproductive performance of treated rams with vitamin $\mathrm{E}$ and selenium was revealed previously through published data by (Balicka-Ramsisz et al., 2006). There are relationship between live body weight and the weight of both testes and also testes volume and testes circumference. Kassab (2007) and Zanouny (2011) reported that significantly correlation coefficient between live body weight and the previous parameters.

The concentration of Se in body tissues is depending on a number of factors such as the chemical forms, the length of time over which its consumed ,the amount of Se provided by the diet, species of animal as well as the type of tissue. Pond et al., (1995) indicated that tissue concentration of Se influence by the amount and chemical forms of Se in the diet. In addition,Juniper et al., (2009) found that with the exception of kidney tissue, all other tissue showed increasing the concentration of Se as a result of supplement different sources of Se in the diet, which can be effect on the improvement in Se availability retention. Antunović et al., (2009 and 2014) concluded that Se inorganic form had a better bioavailability compared to theinorganic form. Marai et al., (2009) reported that supplementation selenium in the ration improved reproductive performance in sheep. Also, Mahmoud et al., (2013) concluded that injections of combination of Vit. E and Se during the breeding season improved the overall reproductive performance of Ossimi rams. In addition, Behne et al., (1996) indicated that testosterone concentration and function are affected by severe selenium deficiency and such element is necessary for testosterone synthesis. Generally, testosterone production increased in rams with more sexually active than rams of low sexual active or sexual inactive (Stellflug et al., 2004). Also, Matos and Thomas, (1991) reported close correlation between testes size and plasma LH, FSH and testosterone concentrations. There are variations in the references which studied the effects of selenium supplementation in the diet on thyroid hormones activity in blood. Some investigators showed that thyroid hormones secretion could be modified as a results of supplementation different Se sources in the diet of animals (Rock, et al., 2001,Shinde, et al., 2009, Soliman, et al., 2012, Alimohamady, et al., 2013 ,Antunović et al., 2014 and Kassab and Mohammed, 2014). They documented that selenium is essential for thyroid hormones secretion and selenoperoxidase protect the thyroid gland from peroxide produced during the synthesis of hormones. Contrarily, Kumar, et al., (2008 and 2009) and Mudgal, et al., (2008) indicated that no effect of supplementation of selenium in the diet on the amount of thyroid hormones secretion in blood. Few studied were carried out with sheep, which indicate the metabolic profile and thyroid hormones activity when fed with different selenium supplementation diets.

The aim of this study was to evaluate the reproductive performance of male lambs, digestibility coefficients, feeding values of ration and some blood parameters as affected by supplementation of different selenium $(\mathrm{Se})$ sources.

\section{MATERIALS AND METHODS}

This experiment was carried out at the Animal Production Experimental Farm, Faculty of Agriculture, Sohag University, Sohag. The climate is dry and subtropical condition.

\section{Experimental design .}

Twenty-four healthy Sohagi male lambs of about 7-8 month of age and an average body weight of $24.47 \pm 0.15 \mathrm{~kg}$ were randomly assigned into four dietary treatment groups (6 animals each). In a feeding trial that extended for 25 -week preceded by two weeks as adaptation period. Basal diet was formulated to meet nutrient requirements according to the NRC (1985) except Se. The diet consists of $30 \%$ wheat straw and $70 \%$ concentrate feed mixture ( CFM). Lambs in group 1 were fed the basal diet as a control (T0), whereas lambs in groups T1, T2, and T3 were fed the basal diet supplemented with $0.1 \mathrm{mg} / \mathrm{kg}$ DM from sodium selenite, vitamin E and selenium and selenized yeast (Se-yeast T3), respectively. The basal diet was formulated to be adequate in protein, energy, vitamins and minerals for this class of animals except for Se content. 


\section{Digestibility and feeding values of the experimental rations.}

At the end of the feeding trial, three rams from each group (average body weight $44.21 \pm 4.90 \mathrm{~kg}$ ) were placed in metabolic cages for digestibility trial. The amount of the daily ration was offered to each animal twice daily and fresh water was available along the day. Five-day preliminary period followed by a collection period of ten days in which daily feces was collected and weighed for each animal. During the collection period of the digestibility trials, the amounts of refused feed were measured daily for each ram for precisely estimate the feed input. Representative samples of feed and feces were taken for proximate analysis according to the method of A.O.A.C. (2000) for dry matter, ash, ether extract, crude fiber and crude protein. Digestion coefficients of all feed nutrients, total digestible nutrients (TDN) and digestible crude protein (DCP) were calculated.

\section{Blood analysis}

Blood samples from three animals in each group were collected before offering morning feed and water via jugular venipuncture at 8.0 a.m. into $10 \mathrm{ml}$ heparinized tubes at $0,1,2,3,4$ and 5 months of the experimental period. Plasma blood samples were then separated by centrifugation blood samples at $3000 \mathrm{rpm}$ for 15 minutes. Testosterone hormone concentration was determined in plasma by the method of Jaffe and Behrman (1974) who performed the assessment of total testosterone concentration using Coat- A- count $\mathrm{I}^{\mathbf{1 2 5}}$. Radioimmunoassay (RIA) kits purchased from diagnostic product corporation, Los Angeles, California, 90045,USA was used.Triiodothyronine and thyroxin concentrations were determined by Radioimmunoassay procedures according to Chopra et al., (1971) and Irvin and Standeven, (1968) by using kits purchased from diagnostic corporation, United States (U. S. A)

At the end of the experimental period three animals were chosen randomly from each group to be slaughtered. Immediately after slaughtering weight of both testes were recorded and a snap of testes was collected and frozen until determination the concentration of Se in testes according to Norheim and Haugen (1986).

\section{Testes measurements}

Testes circumference and testes volume of each lambs were recorded at the beginning of experiment and then at monthly intervals to the end of experimental period. Testes diameter was measured by flexible cloth tape at the point of maximum circumference of the paired testes. Testes volume was evaluated from the volume of water that replaced as described by Salhab et al.,(2001).

\section{Statistical Analysis:}

The results were statistically analyzed using the General Linear Model (SAS, 2008) by using complete randomized design. Different parameters were performed by methods of analysis of variance. All statements of significant difference are based on the 0.05 or 0.01 probability levels. Significant differences among treatments, within the experiment were analyzed using L.S.D (Petersen, 1985).

$\mathbf{Y}_{\mathrm{ij}}=\boldsymbol{\mu}+\mathbf{T}_{\mathrm{i}}+\mathbf{E}_{\mathrm{ij}}$

Where,

$\mathrm{Y}_{\mathrm{ij}}=$ Experimental observation. $\quad \mu=$ The overall mean.

$\mathrm{T}_{\mathrm{i}}=$ The effect of dietary treatment, $\mathrm{i}=\mathrm{T} 0, \mathrm{~T} 1, \mathrm{~T} 2$, and $\mathrm{T} 3$

$\mathrm{E}_{\mathrm{ij}}=$ The errors related to individual observation.

\section{RESULTS AND DISCUSSION}

\section{Nutrient digestibility coefficients}

The effect of different Se sources on digestibility coefficients of nutrients and feeding values of the experimental rations are presented in Table (1). Data showed that ration supplemented with Se-yeast (T3) had higher DM, OM, CP and EE digestibility coefficients than the other three treatments. However, the differences were significantly only between $\mathrm{T} 3$ and both $\mathrm{T} 1$ and control groups.Slightly increases in CF digestibility with all tested rations (T1, T2 and T3) in comparison with control one (T0), while NFE digestibility was significant higher for all tested rations than control one. Mostly organic Se supplements (T2\&T3) had improved significantly the digestion coefficients of most nutrients of the rations in 
comparisons with that supplement by inorganic Se source (T1) control one (T0). The differences between T2 and T3 or between T1 and T2 did not significant respecting all nutrients digestibility's Results reported by Del Razo-Rodriguez at al., (2013) ,Esterhuyse, (2012), Xun, at al., (2012), Shi et al.,(2011) and Wang et al., (2009) are agreement with the previous findings that the digestibility of nutrients and the utilization of supplemental Se were higher than those of control animals. Also, the digestibility of DM in T2 increased than T1 treatments. Similar results have been observed in cattle (Nicholsonet al., 1991 and Ivancic and Weiss, 2001) and in sheep (White and Somers, 1977). In relation to the present results, Hidiroglou at al.,(1968) found that supplementing selenium to sheep had been shown to increase the number of rumen bacteria and also to have some effect on rumen bacterial composition and this might result in improved microbial protein synthesis. Such favorable effect on rumen microbes due to in particular organic Se supplementation could be significantly affecting positively on nutrients, digestibility's of feed. The present results are in agreement with those found by Kholif and khorshed (2006), who concluded that organic Se supplementation to the diets of buffaloes improved rumen activity, nutrients digestibility and milk production. Similar results were recorded by kholif and kholif (2008) who tested Selenium enriched yeast supplementation with the rations of lactating buffaloes. In addition Abdou, Ahlam (2011) supplementation selenium enrich yeast to the diets of goats had improved the nutrient digestibility's of DM ,OM, CP, EE, CF, NFE, NDF, ADL, hemicellulose and cellulose compared with control free from Se supplement. She was added that organic Se improved rumen fermentation and utilization and absorption of minerals and consequently improving goat kids performance. Finally with growing rabbits, Ali et al (2011) results revealed that nutrients digestibility (OM,CF and NFE) were significant improved by using diet supplemented with Selenium active dried yeast compared to control one .

Table (1): Effect of different selenium sources on digestibility coefficient and feeding values of experimental rations.

\begin{tabular}{|c|c|c|c|c|}
\hline \multirow[t]{2}{*}{ Item } & \multicolumn{4}{|c|}{ Treatments } \\
\hline & control & $\mathrm{T} 1$ & $\mathrm{~T} 2$ & $\mathrm{~T} 3$ \\
\hline \multicolumn{5}{|l|}{ Digestibility coefficient } \\
\hline Dry matter & $66.66^{\mathrm{C}} \pm 0.56$ & $68.94^{\mathrm{BC}} \pm 0.52$ & $70.31^{\mathrm{AB}} \pm 1.02$ & $71.98^{\mathrm{A}} \pm 0.71$ \\
\hline Organic matter & $69.23^{C} \pm 0.86$ & $70.65^{\mathrm{BC}} \pm 0.45$ & $72.81^{\mathrm{AB}} \pm 1.28$ & $74.97^{\mathrm{A}} \pm 0.37$ \\
\hline Crude protein & $67.05^{C} \pm 0.24$ & $67.59^{\mathrm{BC}} \pm 1.63$ & $70.75^{\mathrm{AB}} \pm 0.40$ & $72.31^{\mathrm{A}} \pm 0.93$ \\
\hline Ether extract & $66.63^{C} \pm 1.09$ & $67.87^{\mathrm{BC}} \pm 1.15$ & $70.07^{\mathrm{AB}} \pm 1.39$ & $72.13^{\mathrm{A}} \pm 0.68$ \\
\hline Crude fiber & $54.82 \pm 1.52$ & $56.16 \pm 0.56$ & $56.87 \pm 1.07$ & $57.74 \pm 0.44$ \\
\hline Nitrogen free extract & $73.81^{\mathrm{B}} \pm 1.45$ & $75.53^{\mathrm{AB}} \pm 0.92$ & $77.76^{\mathrm{AB}} \pm 2.13$ & $80.44^{\mathrm{A}} \pm 0.28$ \\
\hline \multicolumn{5}{|l|}{ Feeding values on DM } \\
\hline Total digestible nutrients (TDN) & $62.99^{C} \pm 0.73$ & $64.27^{\mathrm{BC}} \pm 0.39$ & $66.24^{\mathrm{AB}} \pm 1.10$ & $68.20^{\mathrm{A}} \pm 0.35$ \\
\hline Digestible crude protein (DCP) & $11.08^{\mathrm{B}} \pm 0.04$ & $11.17^{\mathrm{B}} \pm 0.27$ & $11.69^{\mathrm{AB}} \pm 0.07$ & $11.95^{\mathrm{A}} \pm 0.15$ \\
\hline
\end{tabular}

Control $(T 0)=$ Without treatment, $T 1=$ Sodium selenite treatment, $T 2=$ Vitamin $E$ and Selenium treatment. T3= Selenized yeast reatment.

Mean followed different superscript letter within the same row are significant different at $p<0.01$

\section{Feeding values of the experimental rations}

The nutritive values (TDN and DCP) of experimental rations are presented in Table (1). The highest values of TDN and DCP were recorded in T3, but values were insignificant increased than those of T2 and significant increased than those of T1 and control. The values of TDN and DCP in T1 did not differ significantly than control group. The improvement of TDN and DCP values in T3 may be due to enhancing of digestibility coefficients of CP, EE, CF and NFE in response to the organic selenium sources. The results obtained here are in agreement with the results reported by Abdou, Ahlam, (2011) who supplemented the diet of goat with $2.5 \mathrm{~g} / \mathrm{head} /$ day of selenium enriched yeast. Also, the same results and conclusion had been recorded by Ali et al., (2011) with rabbits when supplement their diet with $14 \mathrm{~g}$ selenium treated yeast /100 Kg diet. 


\section{Testes weight and concentration of selenium in testes.}

Data in Table (2) illustrated that testes weight in T3, T2 and T1 recorded higher values in treatment groups compared to control treatment, but the differences among treatments were not significant. Higher value of testes weight in T3 may be due to increasing live body weight in this treatment than the other treatments that in advance owing to increasing TDN and DCP in this treatment than other treatments. This increasing in live body weight led to heavier weight of different organs in animal including testes .

Table (2) Effect of different sources of selenium on weight and selenium concentrations of testes.

\begin{tabular}{lccccc}
\hline \multirow{2}{*}{ Item } & \multicolumn{3}{c}{ Treatments } & \multirow{2}{*}{ \pm SE } \\
\cline { 2 - 5 } & Control & T1 & T2 & T3 & \\
\hline Testes weight $(\mathrm{kg})$ & 0.202 & 0.220 & 0.233 & 0.295 & 0.03 \\
Selenium testes concentration $(\mathrm{mg} / \mathrm{kg})$ & $0.0140^{\mathrm{D}}$ & $0.161^{\mathrm{C}}$ & $0.365^{\mathrm{B}}$ & $0.391^{\mathrm{A}}$ & 0.005
\end{tabular}

Control $(T 0)=$ Without treatment, $T 1=$ Sodium selenite treatment, $T 2=$ Vitamin $E$ and selenium treatment . T3= Selenized yeast treatment,

Mean followed different superscript letter within the same row are significant different at $P<0.01$

Also, the present results illustrated that Se concentration in testis recorded higher $(\mathrm{P}<0.01)$ values in $\mathrm{T} 3$ followed by $\mathrm{T} 2$ and $\mathrm{T} 1$, while the lowest value recorded in control group. The present results are in agreement with those detected by Juniper, et al., (2009) who indicated that Se concentrations generally in all tissues increased as a results of supplementation different Se sources in the diet and also the concentration of selenium in the consumed diets. Investigations on the chemical nature of Selenocompounds of plant origin demonstrated the presence of several selno compound, e.g. selenomethionine, selenocysteine, selenite, selenocystathione, Se-methylselenocysteine and others (Aspila, 1991). So, these forms of Se and other factors like levels of Se intake and protein, Se absorption, animal class and age, minerals status etc. All these factors largely affecting on Se concentrations in body tissues. Regarding the discriminatory effectiveness of organic Se, Khirwar and Arora, (1977) found that much less selenium's is excreted into milk after the dose of selenite than after adose of selenomethionine or feeding natural selenium containing feeds

\section{Testes circumference and testes volume}

Results, concerning the effect of different Se sources on the testes circumference and testes volume are presented in Table(3). The data illustrated that values at the beginning showed no significant differences, while after 1,2,3,4 and 5 months of the experimental period the differences among dietary treatments were significant $(\mathrm{P}<0.01)$.

The present results indicated that $\mathrm{T} 3$ recorded higher $(\mathrm{p}<0.01)$ values of both diameters compared with $\mathrm{T} 2$ , T1 and control groups. These results may be due to the supplementation selenized yeast (Se-yeast) in T3 that led to the increases of live body weight and both testes diameters as a results of improving TDN and DCP in T3 compared to T2, T1 and control treatments (T0 ). Bayoumi, (1999) and Kassab, (2007) found significant relationship between body weight and testicular diameters in calves and in sheep. In addition, in the present study, testes circumference and volume of ram lambs increased gradually with advancing age and these changing greatly be due to the increase in body weight with advancing age. These results are agreement with those reported by Salem (1997), Kassab (2007) and Zanouny, (2011). They observed that testicular measurements in ram lambs increased gradually with advancing of age until reaching puberty. In addition, Salhab et al., (2001) added that the age and live body weight of Awassi ram lambs were positively affecting on testicular volume. The same results were obtained by Hamdon, (2005) in choise and farafra sheep.

\section{Plasma testosterone concentrations}

The values of testosterone concentrations $(\mathrm{ng} / \mathrm{ml})$ at the beginning showed insignificant differences among treatments, while after one, 2, 3, 4 and 5 months of the experimental period there were significant $(\mathrm{P}<0.01)$ differences $($ Table, 4$)$. The testosterone concentrations in the groups supplemented with selenized yeast (Se-yeast T3 and vitamin E and selenium (T2) were higher than that in the group supplemented with sodium selenite (T1) and control group (T0). These results may be due to organic selenium source in T3 and T2 led to increase in the nutritive values of rations as TDN and DCP. 
Increasing TDN and DCP in T3 and T2 as a results of organic selenium source improve live body weight and consequently the tests weight was increased (Table2).Organic selenium is more efficient in increasing plasma selenium content and selenium-supplemented animals a mountain plasma selenium level longer when depleted, that affected on the vital role of Se on the metabolic processes in general and generated of hormones in specific ( Aspila, 1991). In addition the multi-functional metabolic processes of Se is including GSH-Px that being the most important compound containing seleno cysteine which have a very important role in Se metabolism. Kaur and Bansal, (2004) demonstrated that the levels of testosterone, FSH and LH were significantly reduced during Se deficiency. Generally, testosterone production increases in rams with more sexually active than rams of low sexually active or sexually inactive (Bearden and Fuquay, 1997 and Stellflug et al., 2004). The significant increases of testosterone in treated rams are inconsistent with results of Marin-Guzman et al., (2000)

Table ( 3 ): Effect of different seleniumsources on the testes circumference $(\mathrm{cm})$ and testes volume (ml) in Lambs .

\begin{tabular}{cccccc}
\hline \multirow{2}{*}{ Item } & \multicolumn{3}{c}{ Testes circumference } & \multirow{2}{*}{ A SE } \\
\cline { 2 - 5 } & Control T0 & T1 & T2 & T3 & \\
\hline At the beginning & 12.55 & 12.47 & 12.67 & 12.69 & 0.05 \\
One month & $14.39^{\mathrm{D}}$ & $16.10^{\mathrm{C}}$ & $17.65^{\mathrm{B}}$ & $18.89^{\mathrm{A}}$ & 0.07 \\
2 months & $20.89^{\mathrm{D}}$ & $22.59^{\mathrm{C}}$ & $22.55^{\mathrm{B}}$ & $24.00^{\mathrm{A}}$ & 0.21 \\
3 months & $22.52^{\mathrm{D}}$ & $23.07^{\mathrm{C}}$ & $24.03^{\mathrm{B}}$ & $24.77^{\mathrm{A}}$ & 0.10 \\
4 months & $24.15^{\mathrm{D}}$ & $25.39^{\mathrm{C}}$ & $25.26^{\mathrm{B}}$ & $27.03^{\mathrm{A}}$ & 0.13 \\
5 months & $26.07^{\mathrm{D}}$ & $26.84^{\mathrm{C}}$ & $28.18^{\mathrm{B}}$ & $29.36^{\mathrm{A}}$ & 0.19 \\
& & & Testes volume & \\
At the beginning & $51.67^{\mathrm{D}}$ & $50.67^{\mathrm{D}}$ & $49.67^{\mathrm{B}}$ & $52.33^{\mathrm{B}}$ & 1.04 \\
One month & $71.67^{\mathrm{D}}$ & $91.00^{\mathrm{C}}$ & $99.67^{\mathrm{B}}$ & $114.00^{\mathrm{A}}$ & 1.51 \\
2 months & $128.33^{\mathrm{D}}$ & $133.00^{\mathrm{C}}$ & $140.67^{\mathrm{B}}$ & $166.33^{\mathrm{A}}$ & 3.94 \\
3 months & $153.33^{\mathrm{D}}$ & $167.67^{\mathrm{C}}$ & $183.67^{\mathrm{B}}$ & $197.67^{\mathrm{A}}$ & 1.31 \\
4 months & $172.33^{\mathrm{D}}$ & $188.33^{\mathrm{C}}$ & $215.33^{\mathrm{B}}$ & $249.00^{\mathrm{A}}$ & 2.74 \\
5 months & $191.00^{\mathrm{D}}$ & $208.00^{\mathrm{C}}$ & $244.67^{\mathrm{B}}$ & $282.33^{\mathrm{A}}$ & 2.20 \\
\hline
\end{tabular}

Control $(T 0)=$ Without treatment, $T 1=$ Sodium selenite treatment, $T 2=$ Vitamin $E$ and selenium treatment. T3= Selenized yeast treatment,

Mean followed different superscript letter within the same row are significant different at $P<0.01$

Table (4). Effect of different selenium sources on plasma concentration (ng/ml) of testosterone in lambs

\begin{tabular}{cccccc}
\hline \multirow{2}{*}{ Item } & \multicolumn{4}{c}{ Treatments } & \multirow{2}{*}{ \pm SE } \\
\cline { 2 - 5 } & Control & T1 & T2 & T3 & \multirow{2}{*}{ At the beginning } \\
One month & 0.65 & 0.67 & 0.66 & 0.68 & 0.01 \\
2 months & $0.71^{\mathrm{C}}$ & $0.81^{\mathrm{B}}$ & $0.89^{\mathrm{A}}$ & $0.90^{\mathrm{A}}$ & 0.02 \\
3 months & $0.97^{\mathrm{C}}$ & $1.02^{\mathrm{B}}$ & $1.05^{\mathrm{A}}$ & $1.06^{\mathrm{A}}$ & 0.05 \\
4 months & $1.11^{\mathrm{C}}$ & $1.25^{\mathrm{B}}$ & $1.31^{\mathrm{A}}$ & $1.34^{\mathrm{A}}$ & 0.03 \\
5 months & $1.41^{\mathrm{C}}$ & $1.58^{\mathrm{B}}$ & $1.68^{\mathrm{A}}$ & $1.71^{\mathrm{A}}$ & 0.05 \\
& $1.73^{\mathrm{C}}$ & $1.98^{\mathrm{B}}$ & $2.09^{\mathrm{A}}$ & $2.12^{\mathrm{A}}$ & 0.04
\end{tabular}

Control $(T 0)=$ Without treatment, $T 1=$ Sodium selenite treatment, $T 2=$ Vitamin $E$ and selenium treatment. T3= Selenized yeasttreatment.

Mean followed different superscript letter within the same row are significant different at $P<0.01$ 
In addition, EL-Sisy et al., (2008) recorded similar result in goats. Another study showed that treatment with vitamin E and Se led to increase testosterone level. Matos and Thomas, (1992) reported that close correlation between testes size with plasma LH, FSH and testosterone concentrations. Testosterone is essential for the development and maintenance of sexual behavior in rams. In the present study testosterone hormone level of male lambs was gradually increased with advancing of age. This increase may be due the increasing live body weight and also increasing the growth of different body organs including testes, which is consider the main source of testosterone secretion in blood. The same results were reported by Kassab, (2007) and Zanouny, (2011).

\section{Plasma of thyroid hormones concentrations}

Data of thyroid hormones (triiodothyronine and thyroxin) concentrations as affected by supplementation of different Se sources are presented in Table (5).

Table (5 ): Effect of different selenium sources in plasma thyroid hormones concentrations (ng/dl) in lambs.

\begin{tabular}{|c|c|c|c|c|c|}
\hline \multirow{2}{*}{ Item } & \multicolumn{4}{|c|}{ Triiodothyronine } & \multirow{2}{*}{$\pm \mathrm{SE}$} \\
\hline & Control & $\mathrm{T} 1$ & $\mathrm{~T} 2$ & $\mathrm{~T} 3$ & \\
\hline At the beginning & 2.92 & 2.93 & 2.94 & 2.95 & 0.02 \\
\hline One month & $2.89^{\mathrm{C}}$ & $3.00^{\mathrm{B}}$ & $3.15^{\mathrm{A}}$ & $3.21^{\mathrm{A}}$ & 0.04 \\
\hline 2 months & $3.82^{\mathrm{C}}$ & $4.30^{\mathrm{B}}$ & $4.92^{\mathrm{A}}$ & $4.97^{\mathrm{A}}$ & 0.04 \\
\hline 3 months & $4.15^{\mathrm{C}}$ & $4.40^{\mathrm{B}}$ & $5.03^{\mathrm{A}}$ & $5.10^{\mathrm{A}}$ & 0.06 \\
\hline 4 months & $4.08^{\mathrm{C}}$ & $4.44^{\mathrm{B}}$ & $4.70^{\mathrm{A}}$ & $5.05^{\mathrm{A}}$ & 0.15 \\
\hline \multirow[t]{2}{*}{5 months } & $4.50^{\mathrm{C}}$ & $4.92^{\mathrm{B}}$ & $5.27^{\mathrm{A}}$ & $5.28^{\mathrm{A}}$ & 0.05 \\
\hline & \multicolumn{5}{|c|}{ Thyroxin } \\
\hline At the beginning & 63.20 & 63.30 & 63.35 & 63.40 & 0.92 \\
\hline One month & $70.67^{\mathrm{C}}$ & $84.73^{\mathrm{B}}$ & $88.41^{\mathrm{A}}$ & $89.06^{\mathrm{A}}$ & 1.33 \\
\hline 2 months & $89.92^{\mathrm{C}}$ & $98.74^{\mathrm{B}}$ & $105.97^{\mathrm{A}}$ & $106.29^{A}$ & 1.47 \\
\hline 3 months & $81.32^{C}$ & $86.44^{\mathrm{B}}$ & $95.61^{\mathrm{A}}$ & $97.15^{\mathrm{A}}$ & 1.48 \\
\hline 4 months & $91.90^{\mathrm{C}}$ & $96.60^{\mathrm{B}}$ & $102.55^{\mathrm{A}}$ & $103.67^{\mathrm{A}}$ & 1.33 \\
\hline 5 months & $94.30^{\mathrm{C}}$ & $99.81^{\mathrm{B}}$ & $107.31^{\mathrm{A}}$ & $107.90^{\mathrm{A}}$ & 1.78 \\
\hline
\end{tabular}

Control TO = Without treatment, $T 1=$ Sodium selenite treatment, $T 2=$ Vitamin $E$ and selenium treatment . T3= Selenized yeasttreatment,

Mean followed different superscript letter within the same row are significant different at $P<0.01$

Results of thyroid hormone concentrations at the beginning of experimental period recorded no significant differences among different experimental groups, while at 1, 2, 3, 4 and 5 months of the experimental period the concentrations of triiodothyronine and thyroxin hormones of supplemented groups (T3, T2 and $\mathrm{T} 1)$ showed significantly $(\mathrm{P}<0.01)$ higher values compared to control group ( $\mathrm{T} 0)$. Moreover, concentrations of both hormones in the group supplemented with selenized yeast (T3) or vitamin $\mathrm{E}$ and selenium (T2) showed significantly $(\mathrm{P}<0.01)$ higher values than that of group supplemented with sodium selenite (T1). At the same time there was no significant differences between $\mathrm{T} 3$ and $\mathrm{T} 2$ in the concentrations of both hormones. Thus, the present results indicated that selenized yeast or vitamin $\mathrm{E}$ and Se supplementation were more effective in increasing thyroid hormones concentrations in lambs. Similar increases in concentration of both hormones or in triiodothyronine alone were reported 
by Rock et al. (2001), Antunović et al., (2009 and 2014), El- Shahat and Abdel Monem (2011), Soliman et al. (2012),Alimohamady, et al., (2013) and Kassab and Mohammed, (2014) in sheep.

Likewise, the results obtained by Shinde et al., (2009) showed significantly higher activity of triiodothyronine in blood of buffalo calves that were fed with the addition of sodium selenite compared to those without add selenium. Previous study by Awadeh, et al., (1998) noticed that marked increase of triiodothyronine concentration in beef cows and calves as a results of higher intake of selenium. Contrarily, Kumar et al., (2008 and 2009) and Mudgal et al., (2008) did not observed any effect of supplementation $0.15-0.30 \mathrm{mg}$ selenium $/ \mathrm{kg} \mathrm{DM}$ on the amount of both thyroid hormones in lambs and male buffalo calves. Generally, the increasing in the secretion of thyroid hormones in T3, T2 and T1 may be due to 1- Increasing of carbohydrate, fat and protein metabolism, which was reflected in a positive effect on digestibility coefficient of carbohydrate, fat and protein 2- Also, the increasing of TDN and DCP intakes in T3, T2 and T1 groups. There was a positive relationship between energy or protein intakes and the concentrations of the thyroid hormones as reported by Ahmed, (2003), kassab, (2007) and Zanouny, (2011). Also, the present results showed that both triiodothyronine and thyroxin concentrations increased with advantaging of age over all dietary treatments. The present results are in agreement with the results reported by Kassab, (2007) and Zanouny,(2011). Generally, available data indicated that feed Se (organic forms) is takes up more efficiently by plasma and when cows are depleted plasma Se also remains higher in animals fed organic Se than in those fed inorganic Se.

\section{CONCLUSION}

It could be concluded that supplementation of selenium in the ration of sheep specially in the form of selenized yeast (Se-yeast) led to an improvement the digestibility coefficient and feeding values of rations and reproductive performance through the favorable effects on testes weight, testes diameters and testosterone concentration and, as well as thyroid hormones concentrations in blood of male lambs. More detailed investigations including the identification of more and more chemical forms of seleno compounds in the course of metabolism should be conducted to confirm more confusions, recommendations biological functions of this very important element.

\section{REFERENCES}

A. O. A. C. (2000). Official Methods of Analysis, $15^{\text {th }}$ edn. Association of Official Analytical Chemists, Arlington, VA, USA.

Abdou, Ahlam R. (2011). Utilization of saccharomyces cervisiae supplementation for feeding goats in south Sinai. Egyptian Journal of nutrition and Feeds, 14(2):169181.

Ahmed, S. K. S. ( 2003). Studies on energy and protein allowances in ration for pregnant and milk producing buffaloes. Ph. D. Thesis, Fac. Agric., Ain Shams Univ., Egypt.

Ali, F. A. F., R. I. Elkady, H. A.A. Omer, Sh. A. M., Ibrahim and Sawsan M. Ahmed (2011). Response of growing rabbits to diets containing different sources of yeast. Egyptian Journal of nutrition and Feeds, 14(1): 89-98.

Alimohamady, R., H. Aliarabi, A. Bahari and A.H. Dezfoulian. (2013). Influence of different amounts and sources of selenium supplementation on performance, some blood parameters, and nutrient digestibility in lambs. Biological trace element research, 154(1): 45-54.

Antunović, Z., J.Novoselec, T. klapec, S. Avar, B. Mio, and M. Speranda (2009). Influence of different selenium sources on performance blood and meat selenium content of fattening lambs. Italian Journal of Animal Science, 8: 163-165.

Antunović, Z., J. Novoselec,M. Speranda, T. Klapec, S. Avar, B. Mio, and R. Vukovi (2014). Influence of dietary supplementation with selenium on blood metabolic profile and thyroid hormones activities in fattening lambs. Pakistan Veterinary Journal. 34 (2): 224-228.

Aspila, P.(1991). Metabolism of selenite, selenomethionine and feed-incorporated selenium in lactating goats and dairy cows. J. Agric. Sci. Finland 63:1-74. 
Awadeh, F. T., R. L. Kincaid and K. A. Johnson (1998). Effect of level and source of dietary selenium on concentrations of thyroid hormones and immunoglobulins in beef cows and calves. Journal Animal Science, 76:1204-1215.

Balicka-Ramsisz, A., B. Pilarczyk, A. Ramsisz and M. Wiecorek (2006). Effects of selenium administration on blood serum Se content and on selected reproductive characteristics of sheep. Arch. Tierzuecht. 49: 176-180.

Bayoumi, A. A. E. (1999). Studies on using some herbal preparations on the productive and reproductive performance of buffalo and cattle. Ph. D. Thesis, Fac. Agric., El-Minia Univ., Egypt.

Bearden, H. J. and J. W. Fuquay (1997). Applied animal reproduction, $4^{\text {th }}$ ed. Prentice Hall, Upper Saddle River, NJ, USA.

Behne, D., H. Weiler and A. Kyriakopulos (1996). Effects of selenium deficiency on testicular morphology and function in rats. Journal of Reproduction and Fertility, 106(2): 291-297.

Chopra, I. G, D. H. Solomon and G. I. Beall (1971). Radioimmunoassay for majerment of triiodothyronine in human serum. J. Clin. Invest. 50:2033.

Del Razo-Rodriguez, O. E., J. E. Ramirez-Bribiesca,R. Lopez-Arellano,A. L. Revilla-Vazquez,S. S. Gonzalez-Munoz,M. A. Cobos-Peralta and L. R. McDowell. (2013). Effects of dietary level of Selenium and grain on digestive metabolism in lambs. Czech Journal of Animal Science. Enprensa. Aceptado el, 7.

El- Sisy, G. A., A. M. A. Abdel-Razek, A. A. Younis, A. M. Ghallab and M. S. S. Abdou(2008). Effect of dietary zinc or selenium supplementation on some reproductive hormone levels in male baladi goats. Global Veterinaria 2 (2): 46-50.

El-Shahat, K.H. and U.M. Abdel Monem (2011): Effects of dietary supplementation with vitamin E and /or selenium on metabolic and reproductive performance of Egyptian Baladi ewes under subtropical conditions. World Applied Science J., 12:1492-1499.

Esterhuyse, J.J.(2012) . The effects of different selenium sources on the meat quality and bioavailability of selenium in lamb (Doctoral dissertation, Stellenbosch : Stellenbosch University )

Hamdon, H. A. M. (2005). Productive and reproductive traits of Chios and Farafra sheep under subtropical Egyptian conditions. Ph. D. Thesis, Fac. Agric., Assiut Univ., Egypt.

Hidiroglou, M.,D. P. Heaney and K.J. Jenkins (1968). Metabolism of inorganic selenium in rumen bacteria. Can. J. Phsiol. Pharmacol. 64:229-232.

Ivancic, J., and W. P. Weiss (2001) "Effect of dietary sulfur and selenium concentrations on selenium balance of lactating Holstein cows. Journal of Dairy Science. 84.1: 225-232.

Irvin, W. G. and R. M. Standeven (1968). Serum triiodothyronine uptake using coated tharkoal in the assessment of thyroid function. J. Indot. 41:31.

Jaffe, B. M. and H. R. Behrman (1974). Methods of hormones Radioimmunoassay, Academic Press, New York.

Juniper, D. T., R. H. Phipps, E. Ramos -Morales and G. Bertin(2009). Effects of dietary supplementation with selenium enriched yeast orsodium selenite on selenium tissue distribution and meat quality in lambs . Animal Feed Science and Technology,149(3):228-239.

Kassab, A. Y. M. A. (2007). Effect of protected protein on productive and reproductive performance of sheep. Ph. D. Thesis, Fac. Agric., El- Minia Univ., Egypt.

Kassab, A. Y. and A. A. Mohammed (2014). Effect of vitamin E and selenium on some physiological and reproductive characteristics of sohagi ewes. Egyptian Journal Nutrition and Feeds. 17 (1): 9-18.

Kaur, P. and M. P. Bansal (2004). Effect of experimental oxidative stress on steroidogenesis and DNA damage in mouse testis. Journal of Biomedical Science, 11(3): 391-397.

Kholif, S.M. and M.M. khorshed (2006). Effect of yeast or selenized yeast supplementation to rations on the productive performance of lactating buffaloes. Egyptian Journal of nutrition and Feeds9 (2): 193205 .

Kholif, A.M. and S.M. Kholif, (2008). Effect of selenium enriched yeast supplementation on the productive performance of lactating buffaloes. Egyptian Journal of nutrition and Feeds, 11: 187-200. 
Khirwar, S.S. and S.P.Arora. (1977). Incorporation of Se- Selenomethionine in milk proteins of goats. Milchwissenschaft 32:283-284.

Kumar, N.,A. K. Garg, R. S. Dass,V. K. Chaturvedi, V. Mudgal and V. P. Varshney (2009). Selenium supplementation influences growth performance, antioxidant status and immune response in lambs. Journal of Animal Feed Science and Technology, 153(1): 77-87.

Kumar, N., A. K. Garg, V. Mudgal, R. S. Dass, V. K. Chaturvedi and V. P.Varshney (2008). Effect of different levels of Selenium supplementation on growth rate, nutrient utilization, blood metabolic profile, and immune response in lambs. Biological Trace Element Research, 126(1): 44-56.

Mahmoud, G. B., S. M Abdel-Raheem and H. A. Hussein(2013). Effect of combination of vitamin E and selenium injections on reproductive performance and blood parameters of Ossimi rams.Small Ruminant Research, 113:103-108.

Marai, I.F.M., A. El-Darawany, E. A. Ismail and M.A.M. Abdel-Hafez (2009). Reproductive and physiological traits of Egyptian Suffolk rams as affected by selenium dietary supplementation and housing heat radiation effects during winter of the sub-tropical environment of Egypt. Arch. Tierzucht. 52 (4): 402-409.

Marin- Guzman, J., D. C. Mahan and J. L. Pate (2000). Effect of dietary selenium and vitamin E on spermatogenic development in boars. Journal of Animal Science, 78(6): 1537-1543.

Matos, C. A. P. and D. L. Thomas (1992). Physiology and genetics of lesticular size in sheep: a review. Livestock Production Science, 32(1): 1-30.

Mudgal, V., A.K. Garg,R.S. Dass and V.P. Varshney. (2008). Effect of Selenium and copper supplementation on blood metabolic profile in male buffalo (Bubalusbubalis) calves. Biological Trace Element Research, 121(1): 31-38.

National Research Council (NRC), (1985). Nutrient Requirement of Sheep.6th ed. National Academy Press, Washington, DC, USA.

Nicholson, J. W. G.,R.E. McQueen and R.S. Bush. (1991). Response of growing cattle to supplementation with organically bound or inorganic sources of Selenium or yeast cultures. Canadian journal of animal science, 71(3): 803-811.

Norheim, G. and A. Haugen (1986). Precise determination of selenium in tissues using automated wet digestion and an automated hydride generator - atomic absorption spectroscopy system. ActaPharmacolToxicol, 59(Suppl 7):610-612.

Petersen, R.G. (1985). Design and analysis of experiments. Marcel Dekker, Inc., New York.

Pond, W. G., D. C. Church and K. R. Pond (1995). Inorganic mineral elements . In : Basic Animal Nutrition and Feeding (No.Ed.4).Jhon Wiley and Sons . New York . 167-224 .

Rock, M. J., R. L. Kincaid and G. E. Carstens (2001). Effects of prenatal source and level of dietary Selenium on passive immunity and thermo metabolism of newborn lambs. Small Ruminant Research, 40(2): 129-138.

Salem, A. A. (1997). Some reproductive aspects in male sheep. Ph. D. Thesis, Fac. Agric., Assiut Univ., Egypt.

Salhab, S.A., M. Zarkawi, M. F.Wardeh, M. R. Al-Masri and R. Kassem (2001). Development of testicular dimensions and size, and their relationship to age, body weight and parental size in growing Awassi ram lambs. Small Ruminant Research, 40(2), 187-191.

Sanchez-Gutierrez, M., E. E. Garcia- Montalova and G. A.Izquierd- Vega (2008). Effect of dietary selenium deficiency on the in vitro fertilization ability of mice spermatozoa. Cell Biology and Toxicology, 24:321-329.

SAS, (2008). SAS User ś guide: Statistics, SAS Institute Inc., Cary, NC.

Shi, L.,W. Xun,W. Yue,C. Zhang,Y. Ren,L. Shi and F. Lei. (2011). Effect of sodium selenite, Se-yeast and Nano-elemental Selenium on growth performance, Se concentration and antioxidant status in growing male goats. Small Ruminant Research, 96 (1): 49-52. 
Shinde, P.L., R.S. Dass and A.K. Garg (2009). Effect of vitamin E and selenium supplementation on haematology, blood chemistry and thyroid hormones in male buffalo (Bubalusbubalis) calves. J. Animal Feed Science, 18:241-256.

Soliman, E.B., A.K.I. Abd El-Moty, and A.Y. Kassab (2012). Combined effect of vitamin E and selenium on some productive and physiological characteristics of ewes and their lambs during suckling period. Egyptian Journal of Sheep \& Goat Sciences, Vol. 7 (2): $31-42$.

Stellflug, J. N., A. Perkins and V. A. Lavoie (2004). Testosterone and luteinizing hormone responses to naloxone help predict sexual performance in rams. Journal of Animal Science, 82 (11): 3380-3387.

Wang, C.,Q. Liu,W. Z. Yang,Q. Dong,X. M. Yang,D. C. He and Y. X. Huang. (2009). Effects of Selenium yeast on rumen fermentation, lactation performance and feed digestibilities in lactating dairy cows. Livestock Science, 126(1): 239-244.

White, C. L. and M. Somers. (1977). Sulphur-Selenium studies in sheep I. The effects of varying dietary sulphate and selenomethionine on sulphur, nitrogen and Selenium metabolism in sheep. Australian journal of biological sciences, 30(2), 47-56.

Xun, W.,L. Shi, W. Yue, C. Zhang, Y. Ren, and Q. Liu. (2012). Effect of high-dose nano-selenium and selenium-yeast on feed digestibility, rumen fermentation, and purine derivatives in sheep. Biological Trace Element Research, 150 (1-3):130-136.

Zanouny, A. E. I. (2011). Studies on some productive and physiological traits in Osimi sheep. Ph. D. Thesis, Fac. Agric., El- Minia Univ., Egypt. 


\title{
بعض الصفات التناسلية لذكور الحملان و القيمة الغذائية للعلائق المظاف اليها مصادر مختلفة من السيلنيوم
}

\author{
جلال عبدالمطلب عبدالحافظ1 و جمال محمود سلومة2ّ و ايمن يوسف كساب3 و على سليم على² ${ }^{2}$ \\ ا قسم الانتاج الحيوانى ـ كلية الزراعةـ جامعة اسيوط ـ اسيوط

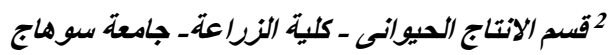

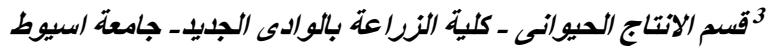

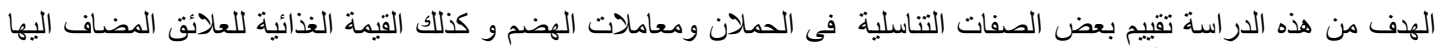

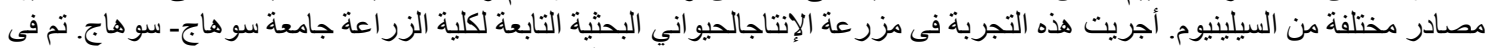

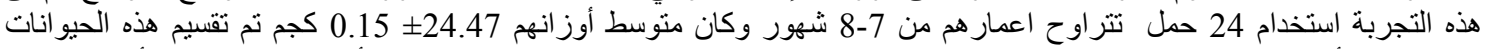

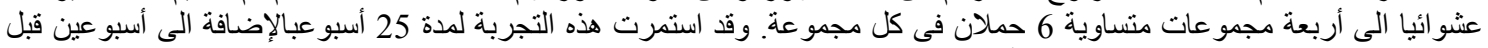

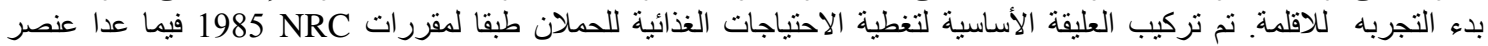

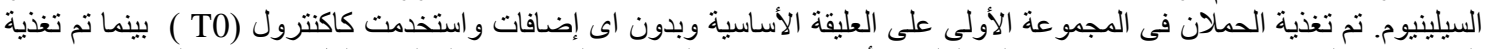

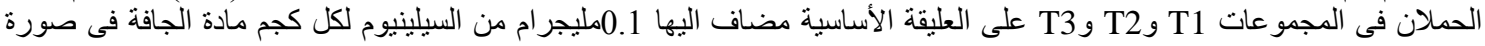

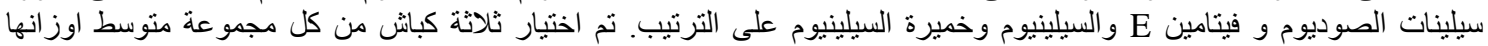

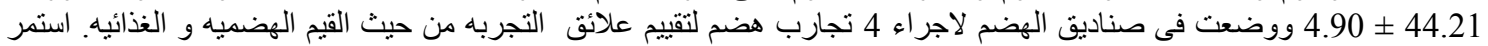

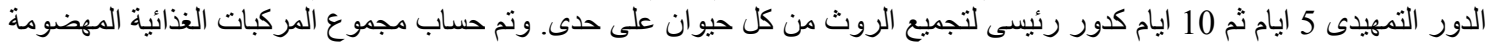
(TDN)

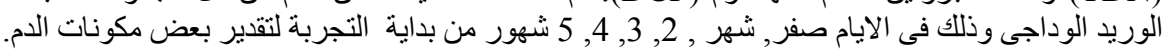

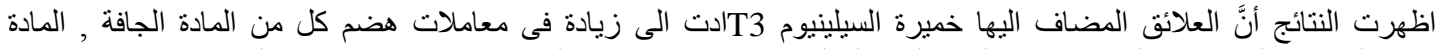

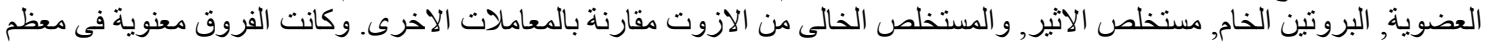

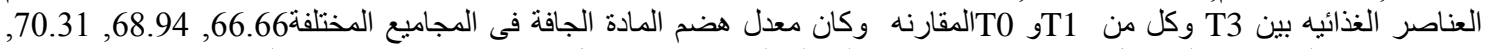

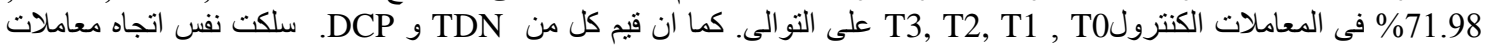

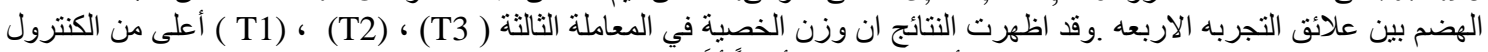

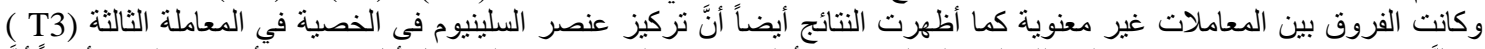

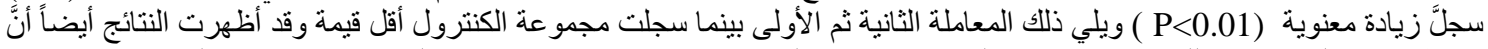

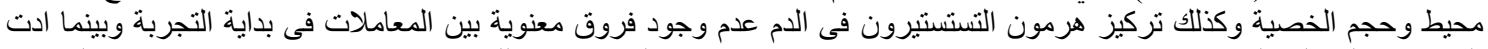

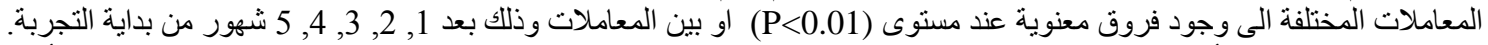

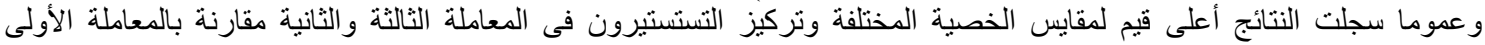

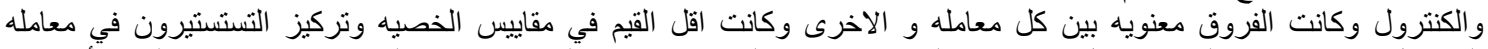

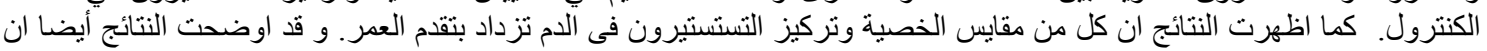

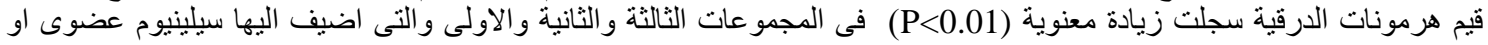

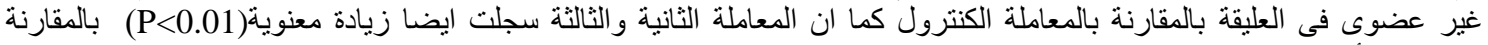

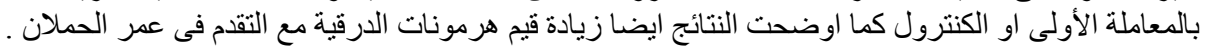

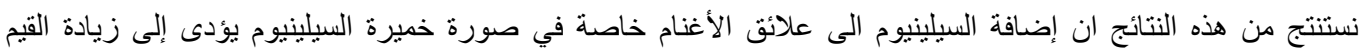

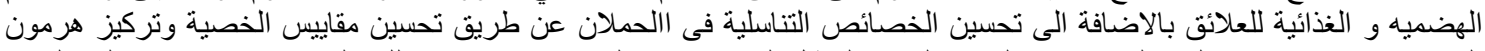
التستشتيرون وهرمونات الغده الدرقيه ذات العلاقه القويه بالتمثيل الغذائى بجسم الحيو انئ وقد انعكس ذلك على الاداء الانتاجى و التناسلى. 